\title{
MYSTICAL SPACE OF NON-CLASSICAL PHILOSOPHY
}

\section{Shabanova Yu. O.}

\section{INTRODUCTION}

Thematic justification of the mystical components of philosophy is based on the current need to recreate the integrity of philosophical methodology. In this vein, holonomic thinking, in which not only logical and rational, but also irrationally intuitive vectors of historical and philosophical continuity are equally carried out, is a popular form of supplementing a holistic vision of a world picture and a person's place in it. The mystical component of philosophy, in its heuristic vector of self-realization, opens the vectors of inclusively semantic updates of the development of modern philosophy. For the foregoing reasons, the object of research of this article is the philosophical mysticism of the XIX - XX century, represented by the works of German scholar Edith Stein and representatives of domestic tradition, such as Mitrofan Vasilievich Lodyzhensky, Piotr Demianovych Uspensky, Boris Petrovych Murav'yov, Daniil Leonidovych Andreev. The appeal to these personalities is due to the insufficient study of their ideas in the modern domestic historical and philosophical space, which requires a substantial supplementing of the objectivity of the historical and philosophical picture, presented both by classical and non-classical directions.

Mysticism is often associated with religious experience, which limits the understanding of the mystical component of philosophy, in which mystical experience can be used outside of a particular confession. The very concept of "mysticism" has several interpretations. Using the exploratory research design method, we are to represent interpretations of the concept of mysticism, which are conditionally divided into several groups:

- a set of phenomena or actions that assist a person in interaction with secret creatures or forces (Egyptian or Eleusinian mysteries, other esoteric rituals, religious rites);

- various forms of occultism, such as: magnetism, magic, theurgy, mediumistic or spiritualistic phenomena;

- doctrine of the internal unity of the human spirit with the absolute Spirit as an adequate knowledge of the ontological fundamental principle of the world through the individual experience of spiritual self-knowledge.

It should be noted that the first definition of mysticism as a combination of ritual and religious actions is associated with archaic cultures, which are characterized by mythological consciousness. As for the second definition of 
mysticism associated with spiritualistic and magical phenomena, it requires a clear differentiation from magic, occult sciences and philosophical mysticism. Thus, the methodological basis of the study is the definition of the concept of mysticism as an act of unity of the universal essence of transcendental reality and the subject of contemplation by expanding the consciousness of the individual "I" to the absolute Spirit, as well as mysticism, in the form of the most adequate expression of the content of mystical experience (spiritual empery) in systematic design of certain teachings.

In this regard, philosophical mysticism seems to be a doctrine organically interconnected with the rich experience of philosophical reflection, stated discursively in the historical and philosophical space.

Philosophical mysticism is a metaphysical discourse about the mystical, as a transcendental reality that forms epistemological and anthropo-axiological representations. So, the concept of "philosophical mysticism" distances itself from the understanding of mysticism in its cult and ritual manifestations; in various forms of occultism; in primitive and philistine ideas.

The key to the definition of philosophical mysticism seems to be the identification of the causes of the mystical vector of worldview, which includes the immanent individual desire for the Absolute, the appeal to the true Being of its own nature.

This eternally inherent desire for a Transcendant is especially aggravated in the critical phases of the development of cultural eras, usually accompanied by extreme forms of rationalism or pragmatism, in the form of opportunistic and simplified worldviews. Then philosophy organically seeks a way out of critical situations, inevitably turning to God, the Divine, the Absolute, which allows expanding the boundaries of the worked-out system and form an evolutionarily demanded new system of views. The path to its formation is mystical insights, subsequently designed as logical and rational systems.

It should be noted that the development of these directions in the European continuum is observed not historically-sequentially, but parallelinterconnectively. So in modern forms of mystical worldview, one can observe the manifestation of signs of all three forms of mysticism.

In the European context, the transpersonal (mystical) metaphysics seems to be the point of suppression of esotericism, doctrinality and speculativeness. Transpersonal metaphysics is an abstracted and metaphysical system based on sacred knowledge that contributes to the expansion of the heuristic and conceptual boundaries of anthropogenesis through the reintegration of all possible epistemological divisions.

At the turn of XIX - XX centuries, philosophical mysticism acquires an original manifestation, realizing all of the above functions on the basis of the philosophical and worldview picture of its time, expanding the system of non- 
classical philosophy. These are the teachings of the German scholar Edith Stein and a number of thinkers such as Mitrofan Vasilievich Lodyzhensky, Piotr Demianovych Uspensky, Boris Petrovych Murav'yov, Daniil Leonidovych Andreev of the turn of the XIX and XX centuries, who for the most part represented the domestic tradition abroad.

\section{General cultural and mystical context of views development of those representatives of "Eastern Christian esotericism"}

The theoretical and world outlook area of the home culture at the end of $19^{\text {th }}$ and $20^{\text {th }}$ centuries is a kind of bosom in which content specificity of the "Eastern Christian esotericism" naturally takes its shape.

First of all, it is Russian religious philosophy on behalf of N.A. Berdiaiev, V.S. Soloviov, S.N. Bulgakov, S.N. and E.N. Trubetskih with the specific to it deep orthodox roots and rethinking of theosophy in its own kind. The idea of soficity and searchings for the synthesis of knowledge influenced synthetic methodology and holistic ontology of P.D. Uspensky, M.V. Lodyzhensky, B.P. Murav'yov, D.L. Andreev in many ways.

The symbolism of the culture of Silver Age had its impact on the views of those thinkers. One of the grounds for the ontological posture development of the representatives of "Eastern Christian esotericism" is a cosmism, represented by both religious and naturalistic trends according to which human being is organically fitted not only to planet system, but to the whole universe.

The representatives of "Eastern Christian esotericism" was not out of reach from contemporary to them tendencies in scientific knowledge that experienced a swift development. In the views of home esotericists we may find a reflection of the concept of futurology as a modelling of creative presentations on new reality that unites metaphysical and constructive approaches.

On the background of philosophical and world outlook tendencies of that time, theosophy influenced ideological grounding of "Eastern Christian esotericism". The period of the end of $\mathrm{XIX}^{\text {th }}-\mathrm{XX}^{\mathrm{th}}$ centuries is marked by emergence and development of theosophical movement that was getting it own power out of vigorous impulse of H.P. Blavatsky who portrayed part of the ancient teaching on Divine Wisdom as exoteric knowledge, not esoteric one. Regardless the Blavatsky develops her activity in America, India and Europe, Russian intellectuals were aware of and joined to international theosophic movement. In this regard we could mention the names of Elena Pisareva, Anna Philosophova, Sofia Gerye, Anna Kamenskaia, Vera Johnson (niece of Blavatsky who married an american theosophist) who represent 
theosophical activity in Russia and beyond its borders ${ }^{1}$. The most influential idea that inspired considered thinkers was the theosophical idea of synthesis that was akin in its content to soficity of Russian religious philosophy. In this context we speak on both on world outlook synthesis, that unites religious, scientific and philosophical concepts, and on synthesis of Western and Eastern world outlook.

The attitude to theosophy is shaping by influence of ambiguous point of view of representatives of Russian religious philosophy who, on the one hand, strived to argue for an idea of "free theosophy" or "integral knowledge" (Vl. Soloviov), re-think theosophy from the standpoint of orthodox Christology (N. Berdiaev, S. Bulgakov), on the other hand, they criticized an activity so-called 'new theosophists". The polemical context of theosophy contributed to creative actualization of its ideas by representatives of "Eastern Christian esotericism" who reconsidered theosophical ideas on the basis of religious and scientific synthesis. M.V. Lodyzhensky, P.D. Uspensky, B.P. Murav'yov, D.L. Andreev are one of the first home thinkers who have attempted to synthesize religious and philosophical groundings of the teachings from the East and orthodoxy. Let us note that M.V. Lodyzhensky in his monumental work "Mystical Trilogy" uses both traditions of Christian asceticizm and Raja Yoga teachings. P.D. Uspensky put ideological traditions of orthodox Christianity, Sufism, and Indian spiritual practices into his work "The New Model of Universe". Both thinkers were in India and Japan. Their interest to Eastern philosophy and spiritual practices has been expressed in some first and unique at that time attempts to integrate Eastern world understanding in teachings of orthodox Christianity. That happened on the background of almost absence of translated works of Eastern philosophy. It is necessary to note that Mitrophan Vasilievich Lodyzhensky and Piotr Demianovych Uspensky were the members of Theosophical society and for some time were members of the board in Russian section. Uspensky used to be in Adyar where he was hosted with the great honour. Akim Lvovich Volynskiy knew theosophy very well, a friend of Uspensky and Murav'yov, a theatre critic and author of some texts and screenplays the content of which was based on theosophical content. Daniil Leonidovych Andreev had theosophical knowledge in depth. And though he criticized to some extent contemporary to him theosophists, he put theosophical image of the spiritual society "Shadanakara", ideologically akin to "Shambala" into his work "Rose of the World". Thus, their topic was theosophy. The cosmological aspect of their concepts remains theosophical background as a hierarchy of the worlds

${ }^{1}$ After the 1919, many theosophists were compelled to leave Russia and continue their theosophical activity abroad due to their persecutions. 
and many leveled system of interacted structures that compound the universe in evolutionary dynamics of the epochs, races, and planetary periods. At the same time, all these thinkers, including the youngest among them, Daniil Andreev, died due to repressions in 1959, remained deeply religious orthodox people and strived to inscribe theosophical cosmology into orthodox picture of the world. M.V. Lodyzhensky, two years before his death, radically changes his attitude to esotericism and on what he says in Introduction to the third volume of "Mystic Trilogy", deepening into orthodoxy as a pure source of Divine revelation.

\section{Summary of creativity of representatives of "Eastern Christian esotericism"}

Mitrofan Vasilievich Lodyzhensky (1852-1917) - Russian writer and religious philosopher, rational mystic, councillor of State. Member of Theosophical Society, secretary of its Russian section. Main work is "Mystic Trilogy" in three volumes (vol. 1"Superconsciousness and the Ways of Its Achieving", vol. 2 "The Unseen Light", vol. 3 "The Dark Force").

Following a hereditary tradition of nobel family he devoted himself to the state service after resignation as vice-governor in Mogiliov province merged himself to spiritual searching. Mutually valuable was his communication with Leo Nikolaievich Tolstoy, next to whom the family of Lodyzhensky was located. In the second volume of "Mystic Trilogy" Mitrophan Vasilievych describes in detail meetings and conversations with L.N. Tolstoy on Indian philosophy, yoga, theosophy, hypnotism and science.

In "Mystic Trilogy" we experience an influence of theosophy that was expressed in seven-like structure of human being and development of the ways of self-understanding in co-dimension of physical, astral, psychological and other, thinner bodies of the man. An influence of Raja-Yoga in Lodyzhensky teaching was emerging as arguing for the concept of clairvoyance.

In his teaching, Mitrophan Vasylievych turns to development of the notion of superconsciousness and its levels and also argues for corresponding ways of their achievement. Being in India, Lodyzhensky found hindus more religious, than those who were orthodox and theosophy defines as practical teaching based upon an idea of universal religious source. "I think", M.V. Lodyzhensky says, "any prayer, as long as it aimed to God, any prayer is high and great. Who told me that? - Theosophy! And here one can find reconciliation of the whole life, not in dogmas"2. In recognition of the one

${ }^{2}$ Религиозно-философское общество в Санкт-Петербурге (Петрограде): История в материалах и документах: 1907-1917 Т. 2. М.: Русский путь, 2009. С. 65. 
source of all religions the thinker saw the ground for universal reconciliation. The outcome of his searchings become his conversion to mystical revelation and miracle power of enlightenment as an evolutionary stage of human development as a higher exemplars of represented in Christian asceticism of orthodox saints and the teachings of "Loving-Kindness".

Piotr Demianovych Uspensky (1878-1947) was a peculiar thinker, creativity and activity of which have found their reflection in three periods of evolution of his views.

The first period was introspection and the development of his mystic faculty, research of dream and creation of the theory on three phases of consciousness condition as a dream, semi-dream, and wakefulness. According to this theory, semi-dream is a mystic focus on one state an outrageous and real events as the basis of mystic techniques. Within this period of time he is interested in theosophy and antroposophy of Rudolf Stainer, becomes a member of Theosophical Society. He thinks that theosophy "has opened the doors to... new bigger world"3. He creatively re-develops theosophical teaching on races arguing that all human race develops ultimately slowly but traverses to higher form of consciousness. Individuals, who reach out cosmic consciousness and lead civilizations, develop faster. The main stage of this period of creativity is his work "Tertium Organum".

The second period is his meeting with Georgiy Gurjiev ${ }^{4}$, under influence of which Uspensky argues for the concept og "The Fourth way", directed to inner unassisted work on self-consciousness and self-remembrance.

"The Fakir" is a long, difficult, and not reliable way. Fakir works on physical body, on pain overcoming.

The way of monk is a shorter way, more secure and defined clearer. It requires some conditions but before all it requires the faith. For if there is no faith, then man cannot be true monk.

The third way is a way of yogi, the way of knowledge and awareness.

However, there is a fourth way, which is not a combination of three previous. It differs from them, first of all, by that it has no any external renunciation of things because all the work is internal. A man must start to work in those conditions, which he finds himself, for these conditions are best for him. ...In many respects this way is more difficult than others because there is nothing harder than change one self within and without external change" 5 .

\footnotetext{
${ }^{3}$ Успенский П.Д. Новая модель Вселенной. СПб. Изд.-во Чернышёва, 1993. С. 42.

${ }^{4}$ Gurjiev Georgiy Ivanovych, a traveler, mystic who studies spiritual traditions of the East, an author of original teaching on the spiritual self-development.

${ }^{5}$ Успенский П.Д. Четвертый путь. - СПб.: АО “Комплект”, 1995. С. 115.
} 
The works of this period are "The Fourth Way", "In Searchings for Miracle. The Fragments of Unknown Teaching".

The third period differs in views with G. Gurjiev's, and it shows an interest to cosmological ideas of the fourth dimension arguing for learning mysticism from the standpoint of non-linear thinking. He was one of the first, who had his say on the idea of fruitfulness of the synthesis of the ideas of psychology and esotericism. He was living in America, where has founded his school for esoterical work in groups.

The works of that period were: "The New Model of Universe", "Psychology of the Possible Human Development".

Boris Petrovych Murav'yov (1890-1966), a naval officer, migrant, died in Geneva. The most unknown from the pleiad of home theosophistsphilosophers who created a systematic argumentation for esoteric orthodoxy.

Since 1955 is a privat-docent at Geneva University delivered his lectures on esoteric philosophy and the history of Russian diplomacy. The author of scientific works, one of the most fundamental of which is "The. Gnosis" (in three volumes), for which he was conferred a Victor-Emil Michel award. He has organized the Centre for Etudes on esoteric philosophy in Geneva in 1961.

The author of the concept of Esoteric Christianity, declared in the fundamental three volume work "The Gnosis. An experience as Commentary to Esoteric Teaching of Eastern Church" in which he gives a universal approach to genuine esoteric knowledge of "God, man, universe". This is a deep and clearly interpreted teaching on metaphysical, psychological and practical principles of "The Sacred Legend".

Daniil Leonidovych Andreev (1906-1959), was repressed at soviet time, spent more than ten years in prison, where created his main work "Rose of the World" on the basis of his own spiritual experience. Despite the fact that he does not have any reference to theosophy and orthodox Christianity this work has religious character represented by the author's ambition to create a universal model of religion, titled as Interreligion. "Rose of the World" is an image of historical epoch came to replace humanism as the synthesis of Medieval and Humanistic models of society, the epoch in which new religious awareness is represented as dialogical unity of religion, science, and philosophy.

\section{General characteristic of theosophical content of "Eastern Christian esotericism"}

One can conclude from mentioned above that the main trait of home thinkers teachings is esotericism, represented as the synthesis of philosophical and religious teachings of the East, theosophy and orthodoxy.

Esotericism can be understood as an ancient knowledge called as Divine wisdom by theosophy, the knowledge which is hidden in the depth of culture, 
accessible to developing person as long as it is ready to be aware of definite degree of the integral knowledge. Esotericism in understanding of orthodox esotericists is not much a secret knowledge as deep sources of wholeness, sacredness that slips away from the wholeness of its understanding by everyday awareness. P.D. Uspensky defines an esoterics as the next: "The thought on knowledge that is superior to all common types of knowledge and not accessible for ordinary people, the thought of knowledge which exists somewhere and belongs to someone pervades all history of human thought from far distant epochs" . B.L. Murav'yov sharing the views of Uspensky on one ancient single knowledge and its single source reckons that "each of world religions takes its roots from the single Tradition and it is a revelation of the truth, but each one is addressed only to certain part of humanity"7. M.V. Lodyzhensky states that the single esoteric source lies in the ground of both world outlook concept of Raja Yoga and in argumentation of the way of orthodox ascetics awakening.

A peculiar feature of esotericism of the thinkers who are presented by our research is in their appeal to sacred principles of the orthodoxy. Boris Murav'yov, who believes that his teaching is entirely Christian, writes: "And only Christianity from the beginning of its emergence claimed that it is universal and addressed to the entire world, that is, to everyone" ${ }^{\text {. }}$. At the same time, Muraviov reckons that Hermetism retained its sacred character of orthodoxy as an "alive esoterical tradition, the tradition which is, of course, is dearest and protected from profanes, but its very own existence was not a secret and an access to it is open for everyone who has a persistent need in closes acquaintance with it"9. Thus, esotericism in teachings of represented thinkers is based on appealing to universal source as a principle of orthodoxy and the way of widening of consciousness is represented as a spiritual selfdevelopment on the ground of active tradition enriched by the spiritual practices of the East.

A reliance on universal source as a principle of esotericism contributes to aspiration for integrity that underlies the theosophical picture of the world and expressed in ancient thesis "All in all" 10 . On the ground of world understanding of thinkers considered the principle of entire interconnectedness of all substantial commencements is evolved. At the same time, the connection between all subjects happens exactly through that whole in relation to which they are parts. The whole as the all is considered as an open integrity.

\footnotetext{
${ }^{6}$ Успенский. П.Д. Новая модель Вселенной. - СПб. Изд.-во Чернышёва, 1993. С. 23.

${ }^{7}$ Муравьёв Б. Гнозис. Т. 1. К.: София, 1999. С. 15.

${ }^{8}$ Муравьёв Б. Гнозис. Т. 1. К.: София, 1999. С. 15.

${ }^{9}$ Муравьёв Б. Гнозис. Т. 1. К.: София, 1999. С. 12.

${ }^{10}$ Блаватская Е. П. Тайная доктрина. Т. 1. М.: Прогресс-Культура, 1992. С. 55.
} 
In this regard, the ontology of Boris Murav'yov in which the open integrity is a condition for realization of each subject of integrity as a hierarchy of different levels of organized matter is remarkable.

Given theosophical representation finds their natural expression in the sketchiness represented by "The Gnosis" of B. Murav'yov, in the work of P. Uspensky "New Model of Universe", in "Rose of the World" by D. Andreev. The sketchiness, traditionally akin to esoterism performs the function of conceptual symbolism in the studied teaching.

Another common trait of this direction, shaped by influence of theosophy, is intuitivism, grounded on uniqueness of mystical insights of every representative of the direction that finds its expression in the uniqueness of language and the form of interpretation of the teaching.

Based on intuitionism D. Andreev, P. Uspensky, M Lodyzhensky., B. Murav'yov, maintain transsubjective character of cognition due to metalogical principles which aspire for recreation of integral knowledge. Theosophical methodology is based on ternary of epistemological approach as subrational, rational, and superrational principles given in their unity of metahistorical experience in comparison to habitual elements of understanding as non-rational and rational forms.

Metahistoricity is one of defining traits of esoteric teaching. Metahistory is a characteristic of totality of processes of non-material (supermaterial) nature. History, in its turn, is a particular manifestation of metahistorical purports.

Special contribution to metahistoricity development, which is in the ground of cosmogenesis of H.P. Blavatsky was made by Daniil Andreev, who believed that metahistory is "a totality of the processes that lies beyond scientific sight, beyond its interests and its methodology. These processes flow in those slices of other being which being submerged into other fluxes of time and other types of the space are visible sometimes through the process which is perceived by us as a history. These otherworldly processes are closely connected to historical process, define it in to the extent, but not coincide with it and the most discovered on the ways of that specific method of understanding which must be called metahistorical" ". Daniil Andreiev has argued for three consequent stages of intuitivism that define an act of entrance in metahistorical reality, fixation of non-formal experience and reflect oh this experience as systematization of new knowledge.

${ }^{11}$ Андреев Д.Л. Роза мира. М.: Прометей, 1991. С. 31. 


\section{Mystical aspect in philosophical views of Edith Stein}

Personality and doctrine of Edith Stein, well known in philosophical circles of Germany, Poland, France, the United States. Foreign studies can be roughly divided into several thematic groups. The first group is Stein's biography ${ }^{12}$.

The second group is related to the phenomenological period of Stein's work and the reflection on her work in the period of interaction with Edmund Husserl and representatives of the Göttingen School of Phenomenology ${ }^{13}$.

The third group of works is devoted to the analysis of her religious views and problems of Catholic metaphysics and mysticism ${ }^{14}$.

The research group of philosophers from Wroclaw headed by Professor Jerzy Mahnach should be especially distinguished. They hold annual conferences devoted to the reflection of Edith Stein's work with the publication of problematic articles by contemporary philosophers and theologians ${ }^{15}$.

Researchers in post-Soviet countries have not paid much attention to Stein's work. This can be explained on the one hand, - the period of the materialist worldview, renounced all that is connected with theology. On the other, - the small size of the translated primary sources of her work. For instance, at the moment we have only one her work translated into Ukrainian:

${ }^{12}$ Bütow K. Ein wahrhaftiges Leben Edith Stein. Gütersloh: Kiefel, 1999.; Feldes J. Auf den Spuren Edith Steins durch Köln. Köln: Selbstverlag, 2005; Herbstrith W. Das wahre Gesicht Edith Steins. Aschaffenburg: Kaffke, 1987; Herbstrith W. Edith Stein. Ein Lebensbild in Zeugnissen und Selbst-zeugnissen. Mainz: Grünewald, 1993; Koch U. Edith Stein. Eine kleine, einfache Wahrheit sagen. Biographischer Roman. Gießen: Brunnen, 2005.

13 Beckmann B. Phänomenologie des religiösen Erlebnisses. Religionsphilo-sophische Überlegungen im Anschluß an Adolf Reinach und Edith Stein. [Fenomenologiya] Würzburg, Königshausen \& Neumann, 2003. 332 p.; Beckmann-Zöller B. - Gerl-Falkovitz, H.-B. Die unbekannte Edith Stein: Phänomenologie und Sozialphilosophie. [Fenomenologiya] Frankfurt am Main, Lang, 2006. 278 p.; Bejas A. Edith Stein. Von der Phänomenologie zur Mystik. Frankfurt/M, Peter Lang, 1987. 208 p.; Fetz R.L.-Rath M. - Schulz P. Studien zur Philosophie von Edith Stein. Internationales Edith-Stein-Symposium Eichstätt 1991 [Phänomenologische Forschungen]. Freiburg-München, Alber, 1993. 370 p.

${ }^{14}$ Feldes J. Im Kreuz ist Hoffnung. Der Kreuzweg mit Edith Stein. Speyer: Pilger, 1999; Heise I. Einfühlung bei Edith Stein. Überraschende Einblicke in die Doktorarbeit einer sensiblen Heiligen. Wien: Selbstverlag, 2005; Petermeier M. Die religiöse Entwicklung der Edith Stein. Eine Untersuchung zur Korrelation von Lebens- und Glaubensgeschichte. Frankfurt/M.: Peter Lang, 1998; Crvenka M. Entscheidung für Gott. Die Taufe Edith Steins. Leutesdorf: Johannes, 1991; Crvenka M. Gott und ich. Meditationen zu Texten von Edith Stein. Essen: Plöger, 1993; Bejas A. Vom Seienden als solchen zum Sinn des Seins. Die Transzendentalien-lehre bei Edith Stein und Thomas von Aquin. Frankfurt/M.: Lang, 1994.

${ }^{15}$ Edyta Stein, Fenomenologia getynsko-monachijska. Analizy./ Pod redakcja Jerzego Machnacza i Krzysztofa Serafina. Wroclaw, TOTEM, 2015; Edyta Stein, Fenomenologia getynsko-monachijska. Zrodla./ Pod redakcja Jerzego Machnacza i Krzysztofa Serafina. Wroclaw: Drukarnia Cyfrowa On-line, 2014. 
"An Introduction to Philosophy"16 ; another her early work has been translated from German into Russian: "What is Philosophy? Dialogues between Edmund Husserl and Thomas Aquinas" $" 17$ and one edition printed in Moscow of the Stein's last work "The Science of the Cross"

In the views of Stein it attract, first of all, the mystical aspect. Stein's mystical talent allows you to put it on a par with the great Catholic mystics such as Bernard of Clairvaux and Meister Eckhart. Independent opinion on the essence of thinking and the depth of the religious consciousness are Edith Stein as a philosopher, to spiritualize their theoretical Study intuitive innermost desire for life and practice of service to the ideals of the Spirit.

For Stein the question of interaction of philosophy and theology was reflected in the problem of the relation of phenomenology and Thomism. Scientific knowledge of the requirement of reliability is guaranteed, according to Stein, not an axiom of evidence, and the faith that leads her to the tradition of Christian mysticism. In this regard, the mystical component Stein views, pervades all periods of its philosophical work is the subject of this study. So, the main problem of this study is to identify the mystical component in the evolution of the views of Edith Stein: from phenomenology to theology. Objective: to determine the nature of philosophical mysticism, and its significance for the deep understanding of the defining ideas in the philosophical heritage of Edith Stein.

From the variety of definitions of mysticism, which are divided into general cultural, religious (N. Smart, S. Kats), psychological (R. Otto), neuroCognitivist (A. Hardy, C. Tart, A. Damasio) approaches, elected in my study the position of philosophical mysticism as a universal ecstatic experience to overcome or minimize the distinction between subject and object in the process of comprehending the truth, based on the desire for immediate unity with the Transcendent (the Absolute, God).

In this regard, the revision is needed, which has already become a textbook, presentation on the fundamental opposition between scholasticism and mysticism, rational and unrational, as the different onto-epistemological position in philosophy. The value and specificity of Edith Stein opinion is that it is not confined within the same system or methodology, seeking to comprehend the truth directly. In this context, we can talk about the mystical nature of the creative method of Stein, which was not the determining reason

\footnotetext{
${ }^{16}$ Штайн, Е. Вступ до філософії. Переклад з нім. Ілони Терзової. - Жовква: Місіонер, 2011. $-248 \mathrm{c}$.

${ }^{17}$ Штайн, Э. Что такое философия? Разговор Эдмунда Гуссерля и Фомы Аквинского. $\Delta o ́ \xi \alpha /$ Докса. Одесса, 2009. - Вип. 14. - С. 372-394.

${ }^{18}$ Штайн, Э. Наука Креста. Исследование о святом Хуане де ла Крусе / Пер. с нем. Натальи Бакша. М.: Институт философии, теологии и истории св. Фомы, 2008.
} 
and not faith, and the will, approve and justify the mystical unity in the comprehension of truth. Besides, phenomenology, within it is implicitly directed toward the investigation of the real structure of direct experience, which by its nature is approaching a mystical experience.

We can say that phenomenology provides the methodological justification of the fundamental universality of mystical experience, which was the subject conceptualizations for W. James E. Underhill, P. Elmonda. And it is this universality, as the search path of absolute truth, and became the basis of the evolution of the views of E. Stein, not deserved accused by some researchers in the absence of a unified system of its teachings. Thus, the methodological basis of the study is the concept of philosophical mysticism as a combination of theological and philosophical doctrines based on the understanding of the experience of ecstatic union with the Absolute.

In this regard, the revision is needed, which has already become a textbook, presentation on the fundamental opposition between scholasticism and mysticism, rational and unrational, as the different onto-epistemological position in philosophy. The value and specificity of Edith Stein opinion is that it is not confined within the same system or methodology, seeking to comprehend the truth directly. In this context, we can talk about the mystical nature of the creative method of Stein, which was not the determining reason and not faith, and the will, approve and justify the mystical unity in the comprehension of truth. Besides, phenomenology, within it is implicitly directed toward the investigation of the real structure of direct experience, which by its nature is approaching a mystical experience.

So what is mystical in the views of E. Stein? About direct personal mystical experience itself hasn't left Stein credible evidence, as opposed to the revelations described in detail by Jacob Boehme and Heinrich Suso. Rather, Stein can be compared with the great German mystic Meister Eckhart, who left to posterity a mystical texts of the Paris period, radically different from the text of the Latin-scholastic period Eckhart. Significantly, we know only that the familiarity with the text of St. Teresa of Avila opened for Edith Stein mystical nature of Christianity and its predetermined position in the mystique of "Science of the Cross"19.

The starting point to understand the mystical Edith Stein became, in my opinion, her work "What is philosophy? Talking Edmund Husserl and Thomas Aquinas " ${ }^{20}$ in which it refers to the idea of transcendental subjectivity as teleologically organized and reflective characteristics of the Divine

\footnotetext{
${ }^{19}$ Stein E. Kreuzeswissenschaft. Studie über Johannes vom Kreuz. Freiburg: Herder, 2004.

${ }^{20}$ Stein E. Was ist Philosophie? Ein Gespräch zwischen Edmund Husserl und Thomas von Aquino / Erkenntnis und Glaube. Freiburg: Herder, 1993. pp. 19-48.
} 
Absolute. Perhaps, this accentuation Stein Husserlian transcendental subjectivity predetermined its interest in Thomism and Catholic monasticism became the foundation of philosophical theater between Husserl and Toma.

Husserlian phenomenology isn't only the basis Stein views, but also the subject of its special studies. To identify the components in the views of the mystical Stein I have been involved explication and exclusion methods of defining moments in the reception Husserlian phenomenology Edith Stein:

- Stein, understanding that philosophy in general and Husserlian phenomenology in particular, seek to understand the world through the mind perceives a partial failure of the phenomenology of a holistic awareness of the fullness of truth. It means the world as a direct contemplation of essence, which goes beyond the identity of being and thinking. In this regard, the work of "Potency and Act" $(1931)^{21}$, prepared a dissertation habilitovannaya protection in Freiberg University goes beyond the phenomenological perspective, implicitly fitted into the elements of philosophical mysticism, which served as the impetus for her conversion to Thomism.

- Phenomenology, from the point of view of Edith Stein, is, in contrast to dogmatism, kind of criticism. Absolute ontological loss and replacement of structural and cognitive tasks in phenomenology, caused the combination of ontology and epistemology in the views of E. Stein, which is a characteristic feature of philosophical mysticism, where the ontological and epistemological object of the subject in the act of contemplation identical.

- Stein sees the problem of consciousness is broader than phenomenology (which, according to the early Husserl, is egologiey, (what he speaks directly to the "Cartesian Meditations" and "Paris reports"). She seeks to identify consciousness with absolute reality, which is much closer to the act of mystical self-discovery the depth of reality than the study of the structure of consciousness within phenomenology.

- Phenomenology, on the interpretation of Stein, busy learning the essence of one of the possible worlds, in the framework of regional ontologies. In this phenomenology, and it is important for Stein, is not metaphysics, and is a study of the actual world was that Husserl repeatedly emphasized in the "Ideas 1". Lack metaphysical phenomenology and Thomism leads to Stein, where it is potentially already looking for a way out of metaphysics to the level of transpersonal states of consciousness.

- Stein blames transcendentalism for the loss of the world, ignoring the change in the outlook of Husserl - his transcendental turn and genealogy acquaintance with the world.

${ }^{21}$ Stein E. Potenz und Akt. Studien zu einer Philosophie des Seins. Freiburg: Herder, 2005. 
At this time, it solves the most complicated for an internal problem. How to combine their belonging to phenomenology and at the same time to Catholicism and his Philosophical justification - Thomism.

Stein separates the plane of Phenomenology and Thomism, Phenomenology leaving scope reaktsionalnoy reconstruction of the logical structures of our world as one of the possible worlds and ways of knowing. Stein this vision leads her to the outside level - to Thomism, at the inside level - to mysticism and monasticism. Man-spiritual (mystical, holistic) becomes a meeting point for conflicting differences Phenomenology and Thomism from the position of Stein. In the beginning of philosophical research, Stein explores forms of mystical intentions through empathy problem and the concept of intuition.

The problem of empathy (empathy) occupied the minds of many contemporary Stein phenomenology. (Max Scheler, Theodor Lipps, Johannes Volkelt etc.). This originality Stein position is to try to go beyond the phenomenological approach that has found its continuation in the psychological and metaphysical planes of its views.

Stein phenomenology in his doctoral dissertation, "On the problem of empathy", which praised Husserl, though determines the "I" center of consciousness of the person, feels the potency empathy method in going beyond the interpersonal empathy than paving the way for empathy with the transcendental subject. The third stage of empathy empathy, regarded Stein as understanding the experience of others, based on the principle of identity of subject of experience and object of empathy.

In this respect, empathy implicitly contains a model for achieving mystical union, in the form of overcoming the subject-object oppositions anthropological nature, and extrapolating it to overcome subject-object opposition transpersonal content.

Reality defies the human mind, sending it out of sight and expanding consciousness to the existence of different levels of being, which ultimately leads to the mystical immersion in the transcendent through the immanent forms of existential. So Stein comes to empower Christian mysticism existential content. Religious people, as can enter into a psychological state of the neighbor, can enter into ofincluded of the divine state. According to Stein, the study of the religious consciousness gives the most accurate answer to the question of knowledge of the spiritual life of the Person through intuition and empathy in mysticism as a Christ like compassion in the Cross, as a way to Carmel.

Despite the fact that empathy normally refers to ethical area of anthropological relationships, in Stein this concept is considered on the level of metaphysical and ontological argumentations. Phenomenology and 
scholastics approach each other and unite in reason in Thomistic sense, what differs from modern European rationalism, limited character of which is overcome by active character of intuition in constituting proceeding of reason, according to Stein's perspective. In a nutshell, phenomenology and Thomism are bridged, and the bridge is between phenomenological ontology of possible worlds and Thomistic theory of understanding in the ultimate forms of reunion and not the opposition between faith and reason. Their merger is represented in intuition, what in its ultimate sense is mystical act as a unity of immanent subject and transcendent object.

An intuition in Stein is considered as an 'essential perspective' (Wesensschau ) of the immediate consciousness data. This approach draws together Thomism and phenomenological method, for any intuition starts from experience, which Stein considers as pure contemplation that typically corresponds to purification of the structures of consciousness in phenomenology. That is to say, an intuition "catalogs" our peering at. However, an intuitive act requires an intellectual processing. The faith that has its roots in trust in Transcendental is a modus that unites these principles for Stein.

Stein comes to the notion of passive intuition that contributes to mystical act and protects it from subjective arbitrariness. If we recall Meister Eckhart, then passive, trans-subjective, aloof, that is to say, unstipulated (aimless) comes to mind, which is the way to mysticism in which the efforts of the reason perform preliminary and reflective function. Passivity, which is pointed out by Stein, in Husserl is related to the issue of passive synthesis. For theology, this question is rather closer to mystical experience. With this in mind, the starting point in Stein and in phenomenology, as well as in Thomism is an intellectual intuition, regarding to which it points out not to methodological, but to ontological issues.

In mysticism, all possible worlds are represented in ontological Absolute that overcomes regional differentiation. In contrast to Husserl, for whom intuition is associated with cognitive possibilities and is understood as peculiar art of peering at, an art of quick reaction on what was seen, in Stein an intuition is rather a movement into inside the self, an ability to complete the whole image, refusing the subjective and necessity to return to subjectivity.

At the same time, it is about deep genetic spirituality of subjectivity that must not be interpreted in the context of European philosophy, where the spirit is an intellectual autonomy, but in the tradition of Christian mysticism, for which spirit is a condensed image, some "sparkle" that reflects the fullness of the Divine fire, one and the single entity of the immanent subject and transcendent object.

This is how the idea of the self knowledge and discovering God in the self, the essence develops. On the one hand, this is the way to phenomenology that 
studies conscious processes, on the other hand, a reduction of consciousness is so essential, that it turns philosopher into mystic, who researches pure facts of consciousness, factoring entire world out and leaving only the entity of the Transcendent (God). In Stein's philosophical views at her last period, an immanent and transcendent are so interconnected, that only their mystical unity is imagined by her as a form of comprehension of the truth. However, in Stein the mystical does not drops out of phenomenological range, but fills it with new existential sense.

At the same time, an eidetic reduction intuitively comprehends the depth of mystical reality. Mysticism appears as an affirmation of primacy of limitless over limited. Only mystical point of view affords Stein to find out answers on possibility of ascendency to Absolute, which appears to be almost transcendent to Being on the one hand, and to the thought of being, on the other. Absolute is a mystery and the will to self-appearance is in the core of this mystery. Only through the world created by Absolute is possible an appearance of the Absolute. At the same time, the world for God becomes some kind of 'envi ronment of phenomenalisation'. Thus, Stein-phenomenologist meets Steintheologist by means of mystical affirmation of transcendental source of any phenomenon and phenomenon of absolute truth as well.

Theological problem (why God created the world) is solved purely in phenomenological way. God achieves an entity by means of appearance and thus, He achieves His Existence. His entity is transcendence beyond the limits which is similar to Eckhart's notion of Divinity (Gottheit), which is discovered only in mystical unity by means of overcoming any personification, and the way to this is through the complete aloofness. In Stein of her later period there is an image of Night (mystical night) appearing, similarly to Eckhart's Divinity - not demonstrated unity before the separation, the transcendent fullness of Absolute. Simultaneously with the Absolute there is development of the image of the Cross as the way of self-overcoming, an inner way to meet the God who, for the sake of the world, like an Absolute, transcends and creates the world. Thus, Stein equivocally connects Thomistic existence of God and phenomenology with existential anthropological mindset in mystical act of revelation. However, she does not limits herself by "office-like" transcendentalism but enriches the mysticism with existential content of ethical subject and practice of service.

Stein is prone to active mode of existence, and solving the question of subjectivity, she highlights active character of ethical subject in fulfilling the spiritual integrity. The holism in Stein is not an ascetic submersion into the self, but a practical altruism of alive purposefulness.

The bottom-line for Stein's searching becomes an awareness of the fact that Christianity provides an opportunity not only for contemplation on God, 
but also to touch Him, meet Him in the depths of the proper self. According to her opinion, "He is that one alive, a dialogue whom one can start with at any moment".

The faith, as Edith writes, "Wants more than separate truths about the God; it wants God Himself, Who is the truth, the entire God. The faith gives an opportunity to grasp Him, not being able to see Him, though"22. And this is an absolute mystical Christian perspective enriched by existential actualization of alive practice. From the perspective of St. Teresa Benedicta, monastic tradition of seclusion, an isolated life under conditions of 20th century, has somewhat other sense.

An idea of self-value of the inner, sacred and individual, spiritual is realized through the concept of worship and 'sacrificial prayer' which is a union with God. Not the mystical detachment or hermit's life, but mystical tendency towards the Transcendent through the existential character of ontology of the infinite, this is what the main idea of philosophical mysticism and the mysticism of the life deed of Edith Stein.

Following her ideas, Edith Stein was one of the few Carmelite in the whole history of confession, who left recluse life and went out of monastery. She became a secluded not from the world, but for the world! Her creative path reaches an argumentation of Christian philosophy as meta-historical, in which mysticism in its ethical dimension of existential meanings plays a ròle of unification between philosophy of consciousness and Thomistic metaphysics. Her mystical works have theoretical and practical aspects of consolidation on the basis of universal truth and world service, what is especially important for today in Europe and the world as a whole.

\section{CONCLUSIONS}

Philosophy of the XIX - XX centuries, realizing the tendency to synthesis, along with such areas as positivism, analytical philosophy, neo-marxism, etc., actively shifts to mystical and intuitive forms, partially represented by the work of the German scholar Edith Stein and representatives of domestic tradition, such as M.V. Lodyzhensky, P.D. Uspensky, B.P. Murav'yov, D.L. Andreev, each of whom has contributed to the replenishment of integrity on the path to the realization of the depths of eternal philosophy.

The mystical aspect in outlook of Edith Stein is presented as a binding principle between phenomenology and Thomism. Relying on methodological definition of philosophical mystic, as a matching of theological and philosophical doctrines, based upon reflection on experience of ecstatic unity

\footnotetext{
${ }^{22}$ Stein E. Kreuzeswissenschaft. Studie über Johannes vom Kreuz. Freiburg: Herder, 2004. P. 72
} 
with the Absolute, it was shown that phenomenology is implicitly directed towards research of real structure of immediate experience which in all its limits approaches to mystical experience. Not the mind and not the will (that directs knowledge to mystical unity of immanent subject and transcendental object in finding the truth) are defining for the mystical character of Stein's creative method. An empathy, as a model of extrapolation of the principle (of to be get used to the experience of the Other) onto mystical act of overcoming of subject-object opposition of transpersonal content and an intuition, as a movement inside the self, an ability to complete an integral image refusing the subjectivity and bringing back generic, spiritual subject, are considered to be key-constructs of the Edith Stein's evolutionary views development on her way to philosophical mystic. At the same time, mystical does not drop out of the phenomenological series but fills it with new existential meaning. The novelty of the study is in its showing up the productive meaning of philosophical mystics in the creativity of Edith Stein, who enriched contemporary anthropology by metahistorical content of moral and existential meaning assumption on the basis of synthesis of philosophy of mind and Thomistic metaphysics.

Representatives of the domestic tradition, such as M. Vasilievich Lodyzhensky, Piotr Demianovych Uspensky, Boris Petrovych Murav'yov, Daniil Leonidovych Andreev, whose heritage is represented in this study as "Eastern Christian esotericism". In this context, esotericism is defined as a separate area of interdisciplinary knowledge based on closed mystical experience. The basis of philosophical esotericism of Western and Eastern doctrine, is the concept of "religionismus", the subject of study of which is the esoteric source itself - transcendent in the utmost completeness of transcendental thinking. This experience supports the expansion of the historical-philosophical methodology, which includes equally direct implantation into the specifics of the subject of research (mysticism) while maintaining the objective position of the researcher, which allows maintaining the analytical position in a holistic picture of philosophical reflection.

Continuing traditions of domestic religious philosophy represented by the works of N.A. Berdyaev, V.S. Solovyov, S.N. Bulgakov, S.N. and E.N. Trubetskoy, S.L. Frank, representatives of "East Christian esotericism", through the lens of the concept of "sophianism", they form the basis of a holistic ontology. A characteristic feature of Russian philosophy of the XIX $\mathrm{XX}$ centuries, is the principle of direct contemplation of the general in the concrete-singular, individual in the act of the intellectual, subconscious in the creative development of reality by establishing a "living" relationship between consciousness and world integrity. 
In this regard, mysticism (an epistemological stance of overcoming of subject-object opposition) is considered as a means of realization of metahistorical approach which in "Eastern Christian Esoterism" is represented as personal experience of the thinker and his introvert practices which lead to integral knowledge which is disclosed to entire man.

Processing from above mentioned one can conclude that the views of home thinkers united their teachings, owing to common traits, in philosophical and world outlook direction of "Eastern Christian esoterism" are some kind of refraction of mystical teaching. In the conceptual area of "Eastern Christian Esoterism" theosophical ideas has found their creative development as a study on individuality that assesses and compares their own spiritual perspectives with the higher Person as a co-creator of evolutionary universe. This standpoint represents it own kind of challenge to one-sidedness of rational moralism and extreme subjectivism and which lays down the way to Universal individualism through the extended forms of consciousness that can be achieved by means of moral practice of introspection and spiritual designation of the man. An original and with many aspects, deep creativity of P.D. Uspensky, M.V. Lodyzhensky, B.P. Muraviov, D.L. Andreev is waiting for serious researching that will allow to expand in terms of content and enrich by heuristic ideas the area of philosophical senses and theosophical practice of the spiritual man in the course of evolutionary development.

Thus, the mystical tendencies of the teachings represented above contribute to the expansion of the methodology and perspectives of philosophical discourse, which is characterized by the following features:

Paradoxicality as the methodological basis of the antinomy of philosophical thinking, which allows you to grasp with consciousness that is not subject to rational, but is grasped intuitively; Equivocationalism as a superontological principle of absolute ontology; The universal and integral essence of ontological unity as a creative principle of eternal formation; The timeless, atopic basis for the formation of dynamic substantiality; Ontological and epistemological apophatism as the basis of mystical dialectics; Ontologically based consubstantiality of the human and the absolute; Anthroposophical universalism as a transcendentally immanent unity of the self-valuable essence of human being; Psychologization of the gnosioaxiological component of transcendental thinking; Superconfessionality as the worldview foundation of universalism.

The presented characteristics of the philosophical mystic of XIX XX centuries lay the foundation for expanding the discourse on meanings and absolute truth in a new quality of the reconstruction of a holistic man in the culture and philosophy of the early XXI century. 


\section{SUMMARY}

The article deals with the definition of "philosophical mysticism", as well as the analysis of some mystical teachings of the XIX-XX centuries philosophy. Mystical trends are considered as an organic part of the historicalphilosophical space in which rational-systemic directions are complemented by mystic-intuitive ones. The mystical context presented by the teachings of the German scholar Edith Stein and representatives of the national tradition of "East Christian Esotericism" M.V. Lodyzhensky, P.D. Uspensky, B.P. Murav'yov, D.L. Andreev, reveals the possibilities of onto-gnoseological and antropo-axiological integrity replenishing. It is proved that the mystical aspect in the views of Edith Stein is presented as a linking principle between Phenomenology and Thomism. The novelty of the study is in its showing up the productive meaning of philosophical mystics in the creativity of Edith Stein, who enriched contemporary anthropology by metahistorical content of moral and existential meaning assumption on the basis of synthesis of philosophy of mind and Thomistic metaphysics. It is determined that "East Christian Esotericism" is defined as a separate area of interdisciplinary knowledge based on closed mystical experience. The concept of "religionismus" is the basis of philosophical esotericism of the XIX XX centuries domestic thinkers, which studies an esoteric source transcendent in the utmost completeness of transcendental thinking. In this regard, mysticism (an epistemological stance of overcoming of subject-object opposition) is considered as a means of realization of metahistorical approach which in "Eastern Christian Esoterism" is represented as personal experience of the thinker and his introvert practices which lead to integral knowledge which is disclosed to holistic man. The characteristics of the XIX $\mathrm{XX}$ centuries philosophical mysticism are defined, which lay the foundations for expanding the discourse on meanings and absolute truth in a new quality of reconstruction of a holistic man in the culture and philosophy of the metamodern of the beginning of the $\mathrm{XXI}^{\text {st }}$ century.

\section{REFERENCES}

1. Религиозно-философское общество в Санкт-Петербурге (Петрограде): История в материалах и документах: 1907-1917: Т. 2. М.: Русский путь, 2009.

2. Успенский П.Д. Новая модель Вселенной. СПб. Изд.-во Чернышёва, 1993.

3. Успенский П.Д. Четвертый путь. СПб.: АО “Комплект”, 1995.

4. Муравьёв Б. Гнозис. Т. 1. К.: София, 1999.

5. Блаватская Е.П. Тайная доктрина. Т. 1.М.: Прогресс-Культура, 1992. 
6. Андреев Д.Л. Роза мира. М.: Прометей, 1991.

7. Bütow K. Ein wahrhaftiges Leben Edith Stein. Gütersloh, Kiefel, 1999. 2005.

8. Feldes J. Auf den Spuren Edith Steins durch Köln. Köln, Selbstverlag,

9. Herbstrith W. Das wahre Gesicht Edith Steins. Aschaffenburg, Kaffke, 1987.

10. Herbstrith W. Edith Stein. Ein Lebensbild in Zeugnissen und Selbstzeugnissen. Mainz, Grünewald, 1993.

11. Koch U. Edith Stein. Eine kleine, einfache Wahrheit sagen. Biographischer Roman. Gießen, Brunnen, 2005.

12. Beckmann B. Phänomenologie des religiösen Erlebnisses. Religionsphilo-sophische Überlegungen im Anschluß an Adolf Reinach und Edith Stein. Würzburg, Königshausen \& Neumann, 2003.

13. Beckmann-Zöller B., Gerl-Falkovitz, H.-B. Die unbekannte Edith Stein: Phänomenologie und Sozialphilosophie. Frankfurt am Main, Lang, 2006.

14. Bejas A. Edith Stein. Von der Phänomenologie zur Mystik. Frankfurt/M: Peter Lang, 1987.

15. Fetz R.L., Rath M., Schulz P. Studien zur Philosophie von Edith Stein. Internationales Edith-Stein-Symposium Eichstätt 1991. Freiburg-München: Alber 1993.

16. Feldes J. Im Kreuz ist Hoffnung. Der Kreuzweg mit Edith Stein. Speyer: Pilger, 1999.

17. Heise I. Einfühlung bei Edith Stein. Überraschende Einblicke in die Doktorarbeit einer sensiblen Heiligen. Wien: Selbstverlag, 2005.

18. Petermeier M. Die religiöse Entwicklung der Edith Stein. Eine Untersuchung zur Korrelation von Lebens- und Glaubensgeschichte. Frankfurt/M.: Peter Lang, 1998.

19. Crvenka M. Entscheidung für Gott. Die Taufe Edith Steins. Leutesdorf: Johannes, 1991.

20. Crvenka M. Gott und ich. Meditationen zu Texten von Edith Stein. Essen: Plöger, 1993.

21. Bejas A. Vom Seienden als solchen zum Sinn des Seins. Die Transzendentalien-lehre bei Edith Stein und Thomas von Aquin. Frankfurt/M.: Lang, 1994.

22. Stein E. Fenomenologia getynsko-monachijska. Analizy. / Pod redakcja Jerzego Machnacza i Krzysztofa Serafina. Wroclaw: TOTEM, 2015.

23. Edyta Stein, Fenomenologia getynsko-monachijska. Zrodla. / Pod redakcja Jerzego Machnacza i Krzysztofa Serafina. Wroclaw: Drukarnia Cyfrowa On-line, 2014.

24. Штайн Е. Bcmyn до філософiї. Переклад з нім. Ілони Терзової. Жовква: Місіонер, 2011. 
25. Штайн, Э. Наука Креста. Исследование о святом Хуане де ла Kpyce/ Пер. с нем. Н. Бакша. М.: Институт философии, теологии и истории св. Фомы, 2008.

26. Stein E. Kreuzeswissenschaft. Studie über Johannes vom Kreuz. Freiburg: Herder, 2004.

27. Stein E. Was ist Philosophie? Ein Gespräch zwischen Edmund Husserl und Thomas von Aquino / Erkenntnis und Glaube. Freiburg: Herder, 1993.

28. Stein E. Potenz und Akt. Studien zu einer Philosophie des Seins. Freiburg: Herder, 2005.

Information about the author: Shabanova Yu. O.,

Doctor of Philosophical Sciences, Professor, Head of the Department of Philosophy and Pedagogy, National Technical University "Dnipro Polytechnic" 19, Dmytra Yavornytskoho ave., Dnipro, 49000, Ukraine 